\title{
Assessing soil carbon stocks under pastures through orbital remote sensing
}

\author{
Gabor Gyula Julius Szakács ${ }^{1}$, Carlos Clemente Cerri, Uwe Herpin², Martial Bernoux³ \\ ${ }^{1}$ USP/CENA - Lab. de Biogeoquímica Ambiental, C.P. 96 - 13400-970 - Piracicaba, SP - Brasil. \\ ${ }^{2}$ USP/ESALQ - Núcleo de Pesquisa em Geoquímica e Geofísica da Litosfera. \\ ${ }^{3}$ Institut de Recherche pour le Développement/UMR EcoESols "Functional Ecology E Soil Biogeochemistry E \\ Agro-Ecosystems” (Cirad-Inra-IRD-SupAgro), 2 place Viala - Bat. 12, 34060 Montpellier cedex, France. \\ *Corresponding author < cerri@cena.usp.br> \\ Edited by: Luis Reynaldo Ferracciú Alleoni
}

\begin{abstract}
The growing demand of world food and energy supply increases the threat of global warming due to higher greenhouse gas emissions by agricultural activity. Therefore, it is widely admitted that agriculture must establish a new paradigm in terms of environmental sustainability that incorporate techniques for mitigation of greenhouse gas emissions. This article addresses to the scientific demand to estimate in a fast and inexpensive manner current and potential soil organic carbon (SOC) stocks in degraded pastures, using remote sensing techniques. Four pastures on sandy soils under Brazilian Cerrado vegetation in São Paulo state were chosen due to their SOC sequestration potential, which was characterized for the soil depth $0-50 \mathrm{~cm}$. Subsequently, a linear regression analysis was performed between SOC and Leaf Area Index (LAI) measured in the field $\left(\mathrm{LAI}_{\text {field }}\right)$ and derived by satellite $\left(\mathrm{LAI}_{\text {satellite }}\right)$ as well as SOC and pasture reflectance in six spectra from $450 \mathrm{~nm}-2350 \mathrm{~nm}$, using the Enhanced Thematic Mapper (ETM+) sensor of satellite Landsat 7. A high correlation between SOC and LAI field $\left(R^{2}=0.9804\right)$ and $\mathrm{LAI}_{\text {satellite }}\left(\mathrm{R}^{2}=0.9812\right)$ was verified. The suitability of satellite derived LAI for SOC determination leads to the assumption, that orbital remote sensing is a very promising SOC estimation technique from regional to global scale.
\end{abstract}

Keywords: Brazil, leaf Area Index, soil organic carbon, pasture degradation, spectral reflectance, climate change

\section{Introduction}

Global warming by greenhouse gas (GHG) emissions causes major negative implications on global environment and economics nowadays and for the future. $\mathrm{CO}_{2}$ contributes with approximately $60 \%$ of the global warming potential of greenhouse gases and intensive studies are undertaken to understand the complex carbon cycle and its interactions between geosphere and atmosphere. Agriculture sector is able to remove $\mathrm{CO}_{2}$ from the atmosphere depending on land conversion and management (Bernoux et al., 2006; Cerri et al., 2004, 2007, 2010). However, it is necessary to quantify the amount of $\mathrm{CO}_{2}$ removed and stored in the form of organic matter. Thus, there is an increasing demand for estimating SOC on a global scale by fast and inexpensive, but yet accurate estimation, such as remote sensing techniques.

In most cases a higher Net Primary Productivity (NPP), without large nutrient and biomass export by harvest, increases SOC due to higher carbohydrate assimilation through photosynthesis, which is partly stored in the soil (Ingram and Fernandes, 2001).

Hodgson (1990) considers LAI as one of the two variables, which demonstrate strong consistency in relation to pasture NPP. Therefore, this study explored the correlation between SOC and LAI. LAI and LAD (Leaf Angle Distribution) represent the main drivers of canopy reflectance (Asner, 1998). Furthermore, it is legitimate to interpret subsoil information (e. g. SOC.) by analyzing upper soil surface characteristics (e.g. LAI) obtained through satellite images, provided that there is a strong correlation between the subsoil and upper soil data (Levine et al., 2000). Several other authors point out to a good relationship between LAI and spectral vegetation indexes (SVIs) such as the NDVI (Broge and Leblanc, 2001; Gupta and Prasad, 2000; Friedl, 1997; Price and Bausch, 1995). Due to differences in the optical properties of vegetation, Turner et al. (1999) suggest the need for considering the specific vegetation type (e.g. pasture) when establishing and applying LAI-SVI relationships. Since the SVIs can be derived from satellite imagery, SOC estimation based on LAI determination through satellite images represents a useful approach, if a significant correlation between these two parameters can be highlighted.

Several authors also investigated the relationship between soil organic matter and soil reflectance (Henderson et al., 1989; Baumgardner et al., 1970). Hummel et al. (2001) studied the near infrared (NIR) reflectance to predict organic matter of soils, with a standard error from the calibration set of $0.63 \%$ (i. e. the standard error of the estimate in the calibration data in percent soil organic matter). Statistical analysis of soil reflectance and SOC indicated the potential of soil reflectance in visible, NIR, and SWIR bands to provide information about SOC content. In particular, five SWIR bands (1955-1965, 2215, 2265, 2285-2295, and 2315-2495 $\mathrm{nm}$ ) revealed the highest correlation $(\mathrm{r}=-0.964$ or higher) (Henderson et al., 1992). For SOC detection in the field, spectral handheld sensors were designed, based on reflectance spectroscopy of the NIR and SWIR spectra (Reeves et al., 2003; Shonk et al., 1991). Chen et al. (2010) found high correlation $\left(\mathrm{R}^{2}=0.98\right)$ between superficial SOC concentrations of bare soil and a logarithm linear combi- 
nation of image intensity values in the red, green, and blue bands. However, the above-mentioned SOC estimation studies relate either to a field or an aerial remote sensing but not to the orbital remote sensing. So far there has been little research about the spectral relationship between subsurface SOC combined with vegetation/soil reflectance at orbital remote sensing scale. The objective of this study is to explore this relationship.

Pasture is the principal land use in the State of São Paulo, covering about 8 million ha (Pino, 2009). Pasture area corresponds mostly to low fertility soils subject to degradation due to extensive pasture management (Oliveira et al., 1996). Several authors (Fagundes et al., 1999) observed reduced biomass productivity for the majority of these pastures. Better pasture management can reduce this degradation and raise the photosynthesis rate, resulting in SOC sequestration. Pastures under sandy soils and with the popular Brachiaria forage were studied due to their high SOC sequestration potential and representativeness for a large geographic area in South America (Lal et al., 2006; Blanchart et al., 2007). Sandy soils cover $15 \%$ of the Brazilian Cerrado biome (Bernoux et al., 2002) that is the second largest biome in South America (Lal et al., 2006).

\section{Materials and Methods}

The study sites are located at the Southern part of the Brazilian Cerrado biome. This vegetation comprises an intricate mosaic of land cover types, vertically structured as grassland, shrubland, and woodland, with a gently sloping relief, ranging from $450 \mathrm{~m}$ to $600 \mathrm{~m}$ altitude at study sites. The studied pastures are situated in the municipalities of Piracicaba and Anhembi (São Paulo State) (Figure 1). Subsequently, they will be described by their farm names (Barreiro Rico, Bondade, Descalvado and Monjelada).

The climate is humid mesothermic with relatively cold and dry winters ( $\mathrm{Cw}$ according to Köppen), where the monthly average temperature does not exceed $18{ }^{\circ} \mathrm{C}$ (Cwa). Meteorological records of Piracicaba municipality indicate a mean annual temperature of $21.6{ }^{\circ} \mathrm{C}$ and a mean annual precipitation of $1.166 \mathrm{~mm}$ for the studied year 2001 (ESALQ/USP, 2003), which represents a difference of 0.4 $\%$ less for mean annual temperature and $4 \%$ less for mean annual precipitation compared to long term climatic data



Figure 1 - Geographic location of the studied pastures. of Anhembi (29 years) and Piracicaba (81 years) (Embrapa, 2010). The studied soils in all four pastures are characterized as Neossolo Quartzarênico (Brazilian soil classification), which refers to Psamments (U.S. Soil Taxonomy) and Arenosols (FAO classification). Soil particle size distribution was determined by sedimentation (Embrapa, 1979) (Figure 2).

SOC and spectral reflectance of pastures interact with both biophysical and human induced parameters like climate (photosynthetic activity), soil type, land use and management type; only former land use cannot be linked to the surface spectral behavior. The parameter former land use takes into account the recalcitrant SOC fraction (SOC fractions with turnover rates from 200 to 1,500 years) (Parton et al., 1987), which was stored before present land use. This SOC fraction is not linked to presenting spectral behavior. Thus it is desirable, to encounter first, pastures with similar previous land use(s), which, therefore, posses similar amount of stable SOC of the previous land use(s) and second, to encounter relatively "old" pastures, that do not feature anymore the biodegradable SOC fraction of the previous land use(s). Consequently, the SOC fraction, derived from the previous land use(s) is harmonized and minimized, which enables a stronger impact of the SOC derived from the present land use, which can be linked to remote sensing (more surface biomass $>$ more SOC).

The studied pastures were chosen under this premise and were established in 1921 (Barreiro Rico farm), 1968 (Monjelada), 1977 (Bondade) and 1980 (Descalvado). It was not possible to encounter all four pastures with the same age of implementation. This selection represents the best set of pasture aged more than 20 years and with a rather precise land use and management history available. The minimum age of 21 years of pasture installation is superior to the 20 year-timeframe recommended as a minimum either by the methodologies of the Intergovernmental Painel on Climate Change (IPCC, 2000) recommended comparing soil C stocks changes due to land-use change (Bernoux et

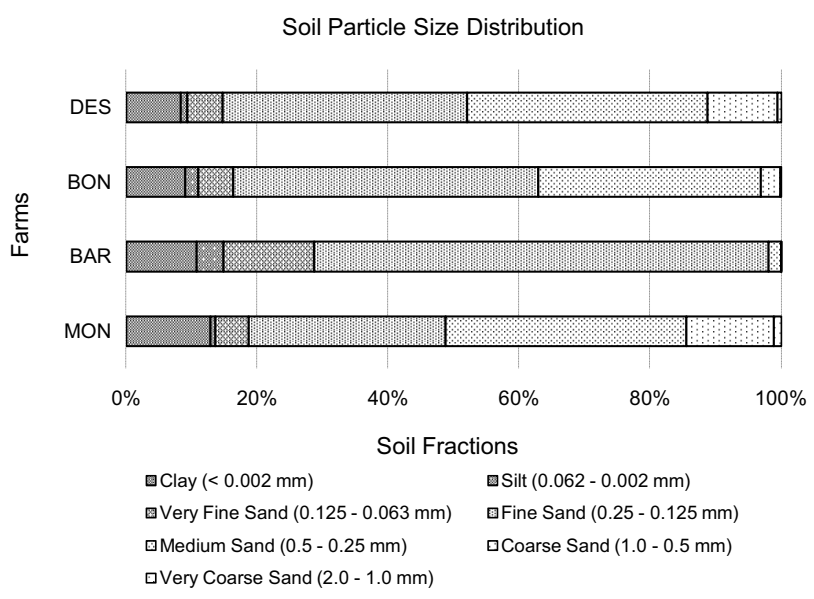

Figure 2 - Soil particle size distribution of the studied pastures. $($ Des $=$ Descalvado $; \mathrm{BON}=$ Bondade; $\mathrm{BAR}=$ Barreiro Rico; $\mathrm{MON}=$ Monjelada).

Sci. Agric. (Piracicaba, Braz.), v.68, n.5, p.574-581, September/October 2011 
al., 2001), either used in international approaches (Milne et al., 2007; Bernoux et al., 2010).

In addition to the selection criteria of pasture age, the four chosen pastures represent four different productivity levels from fairly productive (Monjelada) to fairly unproductive (Descalvado) in order to be able to estimate SOC sequestration potential for sandy soils under pasture in São Paulo State. Each pasture also fulfilled the necessary extension (approximately two hectares) to cover entirely at least one pixel of the satellite image, to ensure a spectral response that is exclusively related to pasture without interferences of other land uses.

Soils were sampled using stainless steel rings $(\varnothing 10$ $\mathrm{cm}$ ) at the following soil depths: $0-5 \mathrm{~cm}, 5-10 \mathrm{~cm}, 10-20$ $\mathrm{cm}, 20-30 \mathrm{~cm}, 30-40 \mathrm{~cm}$ and $40-50 \mathrm{~cm}$, resulting in undisturbed soil samples for further $\mathrm{C}$ and bulk density determination from the same sample (Folegatti et al., 2001). Soil samples were dried to $60{ }^{\circ} \mathrm{C}$ for $\mathrm{C}$ content analysis and an aliquot were dried to $105{ }^{\circ} \mathrm{C}$ for determination of the soil water content in order to allow soil bulk density calculation. The soils were vertically collected for each layer and pasture by six repetitions, except the $0-5 \mathrm{~cm}$ layer (8 repetitions), to account for a higher spatial variability of carbon in the uppermost layer.

For carbon determination, samples were dried for three days at $60{ }^{\circ} \mathrm{C}$. Before weighing, the gross roots were removed. The samples were then sub-sampled by successive diagonal halving to maintain a representative subsample. Before milling, fine roots were removed from the sub-sample. For this purpose, a plastic ruler was electrostatically charged and held over the sub-sample. The electrostatics removed exclusively the fine roots free of soil particles. Finally, the carbon content was determined by dry combustion in a spectrometric carbon analyzer (LECO CN-2000).

The SOC stocks were calculated as follows (Moraes et al., 1996; Ellert and Bettany 1995): SOC $=$ carbon $(\%)$ bulk density ${ }_{\left(\mathrm{g} \mathrm{cm}^{-3}\right.} \times$ depth of soil layer $_{(\mathrm{cm})} \div 100_{\text {(conversion }}$ factor of \%). Bulk density was obtained by dividing dry weight of the undisturbed soil samples trough the volume of the sampling rings (Folegatti et al., 2001).

LAI by field measures: samples were taken in the transition period from wet to dry season in April/May 2001 with intermediate soil humidity to minimize soil sampling distortion errors (Figure 3). At this time of year, the less productive pastures start to suffer water stress, which affects the photosynthetic activity and leads to more visible and desirable differences of LAI between the pastures. The $\mathrm{LAI}_{\text {field }}$ samples were randomly taken by a ring $\left(\varnothing 0.25 \mathrm{~m}^{2}\right)$ in May 30-31, 2001, with 8 repetitions for each pasture. To do so, the litter was removed, followed by an entire cut of the green biomass above the surface. The samples were immediately weighted with the objective of minimizing humidity losses; hereupon approximately $20 \%$ of the entire sample was extracted and immediately weighted to constitute a representative sub-sample. Subsequently, the sub-samples were separated in two fractions: green leaves and others. The green leaves were measured by a Leaf Area Meter (LI-COR: LI-3100). The LAI $_{\text {field }}$ of the entire sample was calculated as follows:

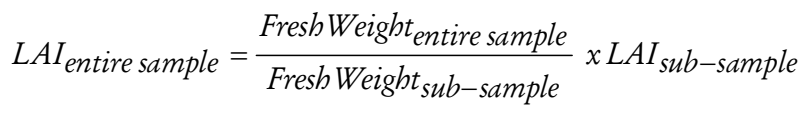

SOC does not exist in its elementary form in nature and is encountered in soils as a component of most diverse chemical complexes. Therefore, SOC does not have specific spectral reflectance behavior and cannot be measured directly by remote sensing techniques. In order to estimate SOC by remote sensing, a parameter has to be used as a link between SOC and terrestrial surface reflectance, which represents a strong correlation to both of them. Therefore, the study investigated the suitability of LAI for this purpose. We used a Landsat 7 satellite image, which represents one of the global standards in remote sensing of terrestrial resources (USGS, 2009). The scene (World Reference System: 220/76) was recorded at $13 \mathrm{~h} 00$ UTC (Universal Time Convention) on the $10^{\text {th }}$ of May 2001 to guarantee close spectral relationship between the land cover satellite scene and LAI sampling (30/31 of May). Table 1 features the spectral characteristics of Landsat 7 ETM+ sensor.

Before processing, a sub-image $(\sim 35 \times 12 \mathrm{~km})$ was extracted from the entire scene to enable more accurate georeferencing and increase processing speed. Subsequently, this sub-image was georeferenced (UTM projection with SAD69 datum) and atmospherically corrected. Georeferencing was done by 12 Ground Control Points (GCP), taken by a differential GPS (DGPS) system (TRIMBLE:GeoExplorer II), using Universal Transverse Mercator (UTM) Coordinate Reference System with South American 1969 datum for Brazil. The accuracy is sub-meter (Trimble, 1999), which is considered adequate for the study. The GCPs were taken in locations that were easily recognizable on the satellite image, to ensure precise georeferencing. The GCPs were imported to a Geographic Information System (GIS) (MICROIMAGES:

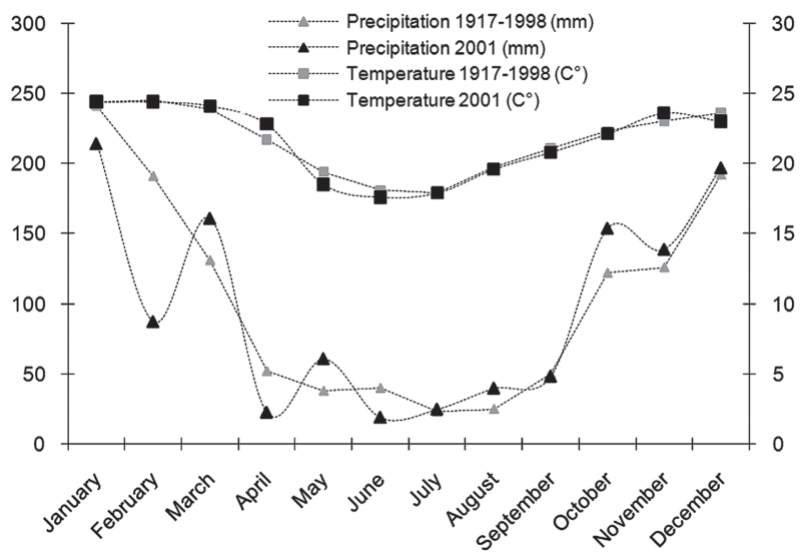

Figure 3 - Monthly precipitation and temperature for the municipality of Piracicaba in 2001 and 1917-1998.

Sci. Agric. (Piracicaba, Braz.), v.68, n.5, p.574-581, September/October 2011 
Table 1 - Characteristics of the spectral bands of Landsat 7 (USGS, 2009).

\begin{tabular}{|c|c|c|c|c|c|c|c|}
\hline \multicolumn{8}{|c|}{ Principal Characteristics of Landsat 7} \\
\hline Band 1 & 2 & 3 & 4 & 5 & 6 & 7 & 8 \\
\hline \multicolumn{8}{|c|}{ Bandwidth $(\mu \mathrm{m})$ : } \\
\hline $0.45-0.52$ & $0.53-0.61$ & $0.63-0.69$ & $0.78-0.90$ & $1.55-1.75$ & $10.4-12.5$ & $2.09-2.35$ & $0.52-0.90$ \\
\hline \multicolumn{8}{|c|}{ Spatial resolution: } \\
\hline $30 \mathrm{~m}$ & $30 \mathrm{~m}$ & $30 \mathrm{~m}$ & $30 \mathrm{~m}$ & $30 \mathrm{~m}$ & $60 \mathrm{~m}$ & $30 \mathrm{~m}$ & $15 \mathrm{~m}$ \\
\hline
\end{tabular}

TNTmips 6.8), using an order 3 polynomial model. The subimage was atmospherically corrected by atmospheric correction software ATCOR-2. Furthermore, the areas of the pastures were marked out by DGPS for adequate identification on the satellite image.

The digital numbers (DN) of the grayscale raster image were converted to surface reflectance (in \%). First, the DNs were converted to apparent radiance by the following formula (Markham and Barker, 1986):

$R A D(\lambda)=\quad \operatorname{gain}($ bigh $) \times D N+$ offset
$R A D(\lambda)=(\operatorname{Lmax} \lambda-\operatorname{Lmin} \lambda) 255^{-1} \times D N+L \min \lambda$

where: $\operatorname{RAD}(\lambda)=$ spectral radiance at the sensor's aperture (W $\mathrm{m}^{-2}$ ster $^{-1} \mu \mathrm{m}^{-1}$ ), Lmin $\lambda=$ spectral radiance range minimum (high gain), $\operatorname{Lmax} \lambda=$ spectral radiance range maximum (high gain), DN = digital number of the considered pixel

The apparent radiance values were then converted to reflectance as follows (Moreira, 2001):

$\rho=\pi \times R A D \lambda \times d^{2} E s o l \lambda^{-1} \times \cos \theta s^{-1}$

where: $\rho=$ planetary reflectance, $R A D \lambda=$ spectral radiance (W $\mathrm{m}^{-2}$ ster $^{-1} \mu \mathrm{m}^{-1}$ ), $\mathrm{d}=$ earth-sun distance, in astronomical units: 1.0109 for the $10^{\text {th }}$ of may (NASA, 2009), Esold = mean solar irradiance $\left(\mathrm{W} \mathrm{m} \mathrm{m}^{-2} \mu \mathrm{m}^{-1}\right)$ (NASA, 2009), $\theta s=$ solar zenith angle $\left(50.6^{\circ}\right)$

$\mathrm{LAI}_{\text {satellite }}$ was calculated in two sequential steps. First the soil fraction covered by plants was calculated, using the following formula proposed by Choudhury et al. (1994):

$F c=1-\left(\frac{N D V I \max -N D V I}{N D V I \max -N D V I \min }\right)^{0.9}$

where: $F c=$ Soil surface fraction covered by plants of given pasture pixel, NDVI = Normalized Difference Vegetation Index of given pasture pixel, NDVImax = Maximum NDVI of studied pasture, NDVI min = Minimum NDVI of studied pasture.

Hereupon, the soil fraction index was used for LAI determination suggested by Campbell and Normann (1998):

$F_{c}=\exp \left(-K_{b e}(0) L_{t}\right)$

where: $F c=$ Soil fraction covered by plants of given pasture pixel, $K_{b e}(0)=$ spherical leaf angle distribution $=$ $0.5, \mathrm{~L}_{\mathrm{t}}=\mathrm{LAI}$.
The equation was re-arranged to be solved for LAI:

$L A I=-2 \operatorname{Ln}(1-F c)$

where: $L A I=$ Leaf Area Index of given pasture pixel, $F c=$ Soil fraction covered by plants of given pasture pixel

Linear regression analysis was performed to evaluate the suitability of field measured LAI and spectral reflectance behavior of pastures, particularly satellite derived LAI, for SOC estimation. Correlation values with a probability higher to $95 \%(p<0.05)$ were considered significant.

\section{Results and Discussion}

The LAI values for the studied pastures, ranging from 0.150 to $1.103 \mathrm{~m}^{2} \mathrm{~m}^{-2}$, which represents a difference of $635 \%$ between the highest LAI pasture and the lowest LAI pasture (Figure 4). The overall low LAI levels found in these pastures are associated to a sandy soil texture. The LAI differences are caused by different management practices, considering that the bio-physical factors bearing an influence on the LAI are almost identical among all pastures (same soil type, forage, climate, topography). The management practices differ in manuring and overgrazing. The two pastures with lower LAI have no manuring and the pasture with the lowest LAI also is overgrazed. The partly bare soil spots in the pasture Bondade are responsible for the high standard deviation.

The individual soil layers $(0-5,5-10,10-20,20-30,30-40$ and $40-50 \mathrm{~cm}$ ) were amalgamated as one soil layer $(0-50 \mathrm{~cm})$. The differences in SOC between the four studied pastures range from 32.0 to $54.4 \mathrm{Mg} \mathrm{ha}^{-1}$, which amounts to a difference of $70.1 \%$ between the highest and lowest SOC (Figure 5). The overall low SOC stocks found in the four pastures are caused by their sandy soil texture (Batjes, 1996). The differences in SOC reflect different management practices, as seen for LAI differences, because the biophysical parameters remain the same for the four pastures (climate, soil type, forage specie, topography). Just one parameter is sensitive to SOC but not to LAI, namely former land use(s). That is because the recalcitrant fraction of the SOC (200-1,500 years turnover rates) of the former land use(s) makes part of the present SOC (Parton et al., 1987). As this fraction cannot be detected by remote sensing through biomass and waterleaf content measurements, it is therefore, advisable to minimize this parameter and/or calculate weighing factors first for the age of the present land use and second for the type of former land use(s).

A regression analysis between $\mathrm{SOC}$ and $\mathrm{LAI}_{\text {field }}$ was performed to investigate their correlation (Figure 6). In the ob- 
served range, the regression follows a linear tendency. The high LAI standard deviation of Bondade refers to incomplete plant cover (approx. $75 \%$ ) at this site. Table 2 summarizes the results, revealing a determination coefficient of $\mathrm{R}^{2}=0.98$, which indicates a highly significant correlation between SOC and $\mathrm{LAI}_{\text {field }}(p<0.05)$.

To perform a regression analysis between SOC and pasture reflectance, the DNs were converted to reflectance: First the DNs were converted to radiance (Table 3) and subsequently to reflectance (Table 4). Table 5 shows the result of a regression analysis between SOC and pasture reflectance for six spectral bands and satellite derived LAI. Two determination coefficients $\left(\mathrm{R}^{2}\right)$ were higher than 0.95 , indicating a significant correlation $(p<0.05)$ for the red spectrum vs. SOC and satellite derived LAI vs. SOC. Hence, these two correlations were discussed in detail.

Figure 7 shows the regression analysis between SOC and pasture reflectance in the red spectrum. Taking into account

Table 2 - Regression between soil organic carbon (SOC) and field measured Leaf Area Index $\left(\mathrm{LAI}_{\text {field }}\right)$.

\begin{tabular}{lccc}
\hline \multicolumn{4}{c}{$\mathrm{SOC}=\mathrm{LAI}_{\text {field }} * \mathrm{a}+\mathrm{b}$} \\
\hline $\begin{array}{c}\text { estimate of } \\
\text { the equation }\end{array}$ & $\begin{array}{c}\text { standard } \\
\text { error }\end{array}$ & $p<0.05$ \\
\hline $\mathrm{a}$ & 28.685 & 0.008 & $0.022^{*}$ \\
$\mathrm{~b}$ & 22.766 & 0.367 & 0.048 \\
$\mathrm{R}^{2}$ & 0.9804 & & $0.013^{*}$ \\
\hline
\end{tabular}

$\mathrm{a}=$ gradient, $\mathrm{b}=$ intersection with $\mathrm{y}$-axis, $\mathrm{R}^{2}=$ determination coefficient, *significant correlation with $p<0.05$.

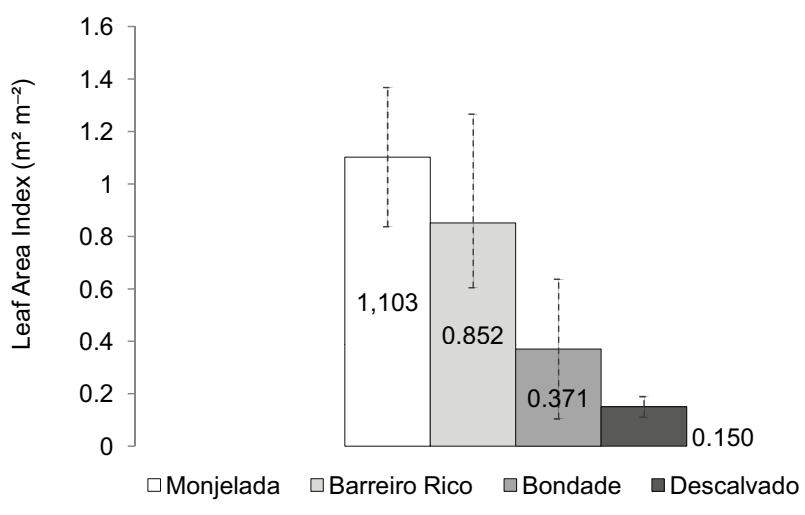

Figure 4 - Leaf Area Index of the pastures by field measures.



Figure 5 - Soil carbon stocks for $0-50 \mathrm{~cm}$, expressing the sum of individual soil layers $0-5,5-10,10-20,20-30,30-40$ and $40-50 \mathrm{~cm}$.

Table 3 - Conversion of digital numbers to radiance.

\begin{tabular}{|c|c|c|c|c|c|c|}
\hline \multirow{2}{*}{ Landsat ETM+ } & \multirow{2}{*}{$\operatorname{Lmax} \lambda$} & \multirow{2}{*}{$\operatorname{Lmin} \lambda$} & \multicolumn{4}{|c|}{ Mean Apparent Radiance (W m ${ }^{-2}$ ster $\left.^{-1} \mu \mathrm{m}^{-1}\right)$} \\
\hline & & & Monjelada & Barreiro R. & Bondade & Descalvado \\
\hline Band 1 (blue) & 191.6 & -6.2 & 36.30 & 39.73 & 41.57 & 41.92 \\
\hline Band 2 (green) & 196.5 & -6.4 & 31.41 & 36.02 & 36.12 & 35.16 \\
\hline Band 3 (red) & 152.9 & -5.0 & 19.66 & 21.29 & 30.95 & 33.27 \\
\hline Band 4 (near infrared) & 157.4 & -5.1 & 52.91 & 62.53 & 46.91 & 41.83 \\
\hline Band 5 (short-wave infrared I) & 31.06 & -1.0 & 7.64 & 9.89 & 11.59 & 12.11 \\
\hline Band 7 (short-wave infrared II) & 10.8 & -0.35 & 1.11 & 1.56 & 2.54 & 2.57 \\
\hline
\end{tabular}

Lmin $\lambda=$ spectral radiance range minimum (high gain), Lmax $\lambda=$ spectral radiance range maximum (high gain).

Table 4 - Conversion of radiance into planetary reflectance.

\begin{tabular}{lcrrrr}
\hline \multirow{2}{*}{ Landsat ETM+ } & \multirow{2}{*}{ Exo-atmospheric Irradiance $($ Esol $\lambda)$} & \multicolumn{3}{c}{ Exo-atmospheric reflectance $(\rho)(\%)$} \\
\cline { 3 - 6 } & & Monjelada & Barreiro R. & Bondade & Descalvado \\
\hline Blue & 1970.0 & $9.32 \pm 0.39$ & $10.20 \pm 0.36$ & $10.67 \pm 0.38$ & $10.76 \pm 0.33$ \\
Green & 1843.0 & $8.62 \pm 0.67$ & $9.88 \pm 0.49$ & $9.91 \pm 0.52$ & $9.65 \pm 0.35$ \\
Red & 1555.0 & $6.41 \pm 0.93$ & $8.55 \pm 1.06$ & $10.09 \pm 0.84$ & $10.85 \pm 0.79$ \\
Near infrared & 1047.0 & $25.63 \pm 2.16$ & $30.30 \pm 1.92$ & $22.51 \pm 1.67$ & $20.27 \pm 1.02$ \\
Shortwave infrared I & 227.10 & $17.00 \pm 2.38$ & $22.03 \pm 2.31$ & $25.80 \pm 1.99$ & $26.97 \pm 2.32$ \\
Shortwave infrared II & 80.53 & $6.94 \pm 1.62$ & $9.83 \pm 2.10$ & $15.96 \pm 2.30$ & $16.13 \pm 2.07$ \\
\hline
\end{tabular}

Note: The average reflectance for each pasture is acquired by the following sum of pixels: (217 Monjelada, 495 Barreiro Rico, 89 Bondade and 89 Descalvado). 
Table 5 - Regression analysis between soil organic carbon (SOC) and pasture reflectance and LAI satellite

\begin{tabular}{|c|c|c|c|c|c|c|}
\hline \multicolumn{7}{|l|}{$\operatorname{SOC}\left(\mathrm{Mg} \mathrm{ha}{ }^{-1}\right)=$} \\
\hline & a & $*$ & Reflectance (\%) & + & $\mathrm{b}$ & $\mathrm{R}^{2}$ \\
\hline & -14.27 & $*$ & Blue $(450-520 \mathrm{~nm})$ & + & 188.9 & 0.882 \\
\hline & -10.87 & * & Green $(530-610 \mathrm{~nm})$ & + & 146.2 & 0.436 \\
\hline & -5.01 & $*$ & $\operatorname{Red}(630-690 \mathrm{~nm})$ & + & 87.7 & 0.959 \\
\hline & +1.64 & $*$ & NIR (780-900) & + & 2.3 & 0.507 \\
\hline & -2.16 & $*$ & SWIR I (1550-1750 nm) & + & 92.4 & 0.939 \\
\hline & -2.08 & * & SWIR II (2090-2350 nm) & + & 68.2 & 0.907 \\
\hline & 18.77 & $*$ & LAI (satellite) & + & 19.7 & 0.981 \\
\hline
\end{tabular}

$\mathrm{a}=$ gradient, $\mathrm{b}=$ intersection with $\mathrm{y}$-axis, $\mathrm{R}^{2}=$ determination coefficient.

the standard deviation of reflectance, there is spectral overlapping between Bondade and Barreiro Rico. This can be caused by a stronger influence of soil reflectance at Bondade due to bare soil spots.

Three of the four pastures feature a developed plant canopy, fully covering the soil, thus diminishing the influence of soil reflectance on the overall pasture reflectance. This leads to the assumption in this experiment that the differences found in pasture reflectance are mainly linked to differences in plant canopy reflectance. The red spectrum suffers spectral absorption by the photosynthetically active pigments of chlorophyll a (absorption max. $675 \mathrm{~nm}$ ) and b (absorption max. 480 $\mathrm{nm}$ ) in the green leaves. This leads to the assumption that photosynthesis is responsible for the highest coefficient of determination between pasture reflectance and SOC.

The regression analysis between SOC and satellite derived LAI (Figure 8) indicates a highly significant correlation $\left(\mathrm{R}^{2}=0.98\right)$ with linear tendency $(p<0.05)$. Over all high standard deviation for satellite derived LAI is explained by the use of logarithm function for $\mathrm{LAI}_{\text {satellite }}$ determination.

The regression analysis between field measured LAI and satellite derived LAI (Figure 9) identifies a relatively linear tendency $(r=0.96, p<0.05)$, however weaker as expected. The relatively low linearity and correlation of the regression can be explained by its "oultlier", the LAI measures of Bondade farm, which is constituted by irregular plant cover. It is believed that $2 \mathrm{~m}^{2}(8 \times 0.25$ $\mathrm{m}^{2}$ ) were not enough to obtain a representative average value for $\mathrm{LAI}_{\text {field }}$ from Bondade. However, satellite derived LAI values were too high for this study, considering that the value 0 of field measured LAI corresponds to value 0.5054 of satellite derived LAI. It is suggested to investigate this regression under different situations for future improvement of satellite derived LAI.

\section{Conclusions}

As SOC does not have specific spectral reflectance behavior and cannot be measured directly by remote sensing techniques, the study investigated first, if SOC can be estimated

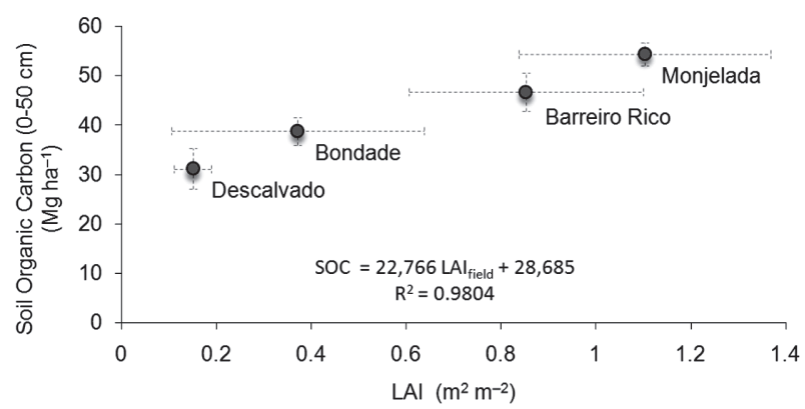

Figure 6 - Regression between Soil Organic Carbon and Leaf Area Index by field measures.



Figure 7 - Correlation between SOC and reflectance in the red spectrum of the studied pastures.

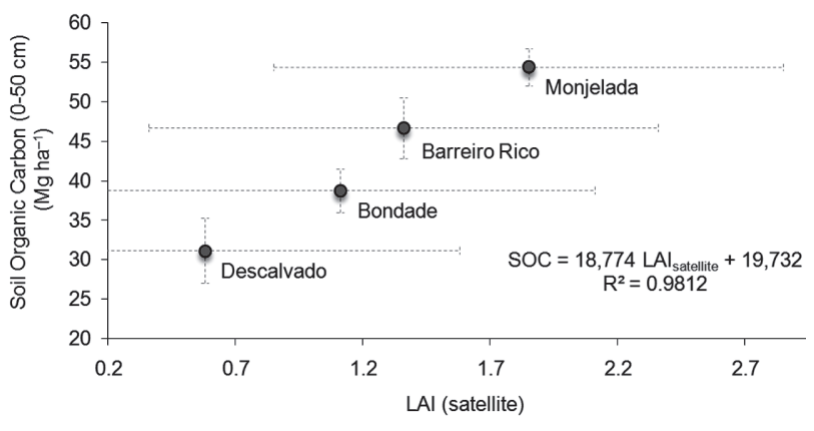

Figure 8 - Regression analysis between SOC and satellite derived LAI of the studied pastures. 


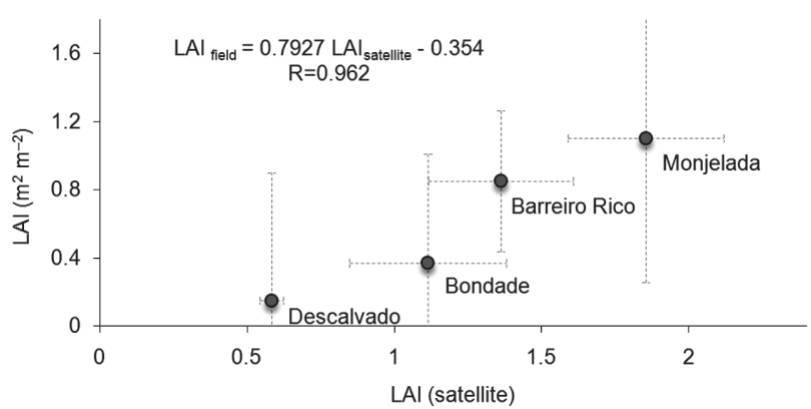

Figure 9 - Regression analysis between field measured LAI and satellite derived LAI of the studied pastures.

by LAI and second, if LAI can be adequately derived from satellite images. A regression analysis between SOC and field measured LAI was significant, showing the suitability of field measured LAI for SOC estimations. Furthermore, a regression analysis between SOC and satellite derived LAI resulted in a highly significant coefficient $\left(\mathrm{R}^{2}=0.9812\right)$ at a significance level of $p<0.05$. The suitability of satellite derived LAI for SOC determination of the studied pastures leads to the assumption that orbital remote sensing is a promising SOC estimation technique for pastures on a regional scale, especially under the scope of major improvements in terms of spatial, spectral and temporal resolution of satellite imagery in recent years. It is acknowledged, that former land use, length of time of the current land use as well as organic matter fertilization have to be taken into account for reliable SOC estimations by orbital remote sensing. Further investigations for the suitability of satellite derived LAI for SOC estimations are suggested for other pastures and land uses.

\section{Acknowledgements}

This research was supported by CNPq Grant Nr. 133344/ 2000-2. Authors thank the IRD for providing Landsat 7 data. Special thanks to Dr. Rudolf Richter for providing valuable information for the atmospheric correction, Dr. Osny Bacchi for providing GPS equipment, and Dr. Carlos Guilherme Silveira Pedreira for assistance at LAI determination. This paper is dedicated to the memory of Vincent Eschenbrenner (1943-2010) who was at the origin of this research.

\section{References}

Asner, G.P. 1998. Biophysical and biochemical sources of variability in canopy reflectance. Remote Sensing of Environment 64: 234253.

Batjes, N.H. 1996. Total carbon and nitrogen in the soils of the world. European Journal of Soil Science 47: 151-163.

Baumgardner, M.F.; Kristof, S.; Johannsen, C.J.; Zachary, A. 1970. Effects of organic matter on the multispectral properties of soils. Indiana Academy of Science 79: 413-422.

Bernoux, M.; Branca, G.; Carro, A., Lipper, L.; Smith, G.; Bockel, L. 2010. Ex-ante greenhouse gas balance of agriculture and forestry development programs. Scientia Agricola 67: 31-40.

Bernoux, M.; Carvalho, M.C.S,; Volkoff, B.; Cerri, C.C. 2001. CO emission from mineral soils following land-cover change in Brazil. Global Change Biology 7: 779-787.
Bernoux, M.; Carvalho, M.C.S.; Volkoff, B.; Cerri, C.C. 2002. Brazil's soil carbon stocks. Soil Science Society of America Journal 66: 888-896

Bernoux, M.; Cerri, C.C.; Cerri, C.E.P.; Siqueira Neto, M.; Metay, A.; Perrin, A.S.; Scopel, E.; Razafimbelo, T.; Blavet, D.; Piccolo, M.C.; Pavei, M.; Milne, E. 2006. Cropping systems, carbon sequestration and erosion in Brazil, a review. Agronomy for Sustainable Development 26: 1-8.

Blanchart, E.; Albrecht, A.; Bernoux, M.; Brauman, A.; Chotte, J.L.; Feller, C.; Ganry, F.; Hien, E.; Manlay, R.; Masse, D.; Sall, S.; Villenave C. 2007. Organic matter and biofunctioning in tropical sandy soils and implications for their management. In: First management of tropical sandy soils for sustainable agriculture: a holistic approach for sustainable development of problem soils in the tropics. 536 p. Available at: http:// www.fao.org/docrep/010/ag125e/AG125E00.htm).

Broge, N.H.; Leblanc, E. 2001. Comparing prediction power and stability of broadband and hyperspectral vegetation indices for estimation of green leaf area index and canopy chlorophyll density. Remote Sensing of Environment 76: 156-172.

Campbell, G.S.; Norman, J.M. 1998 An Introduction to Environmental Biophysics. Springer, New York, NY, USA. p. 268.

Cerri, C.C.; Bernoux, M.; Cerri, C.E.P., Feller, C. 2004. Carbon cycling and sequestration opportunities in South America: the case of Brazil. Soil Use and Management 20: 248-254.

Cerri, C.C.; Bernoux, M.; Maia, S.M.F.; Cerri, C.E.P.; Costa Júnior, C.; Feigl, B.J.; Frazão, L.A.; Mello, F.C.; Galdos, M.V.; Moreira, C.S.; Carvalho, J.L.N. 2010. Greenhouse gas mitigation options in Brazil for land-use change, livestock and agriculture. Scientia Agricola 67: 102-116.

Cerri, C.E.P.; Sparovek, G.; Bernoux, M.; Easterling, W.E.; Melillo, J.M.; Cerri, C.C. 2007. Tropical agriculture and global warming: impacts and mitigation options. Scientia Agricola 64: 83-89.

Chen, F.; Kissel, D.E.; West, L.T.; Adkins, W. 2010. Field-scale mapping of surface soil organic carbon using remotely sensed imagery. Soil Science Society of America Journal 64: 746-753.

Choudhury, B.J.; Ahmed, A.H.; Idso, S.B.; Reginato, R.J.; Daughtry, C.S.T. 1994. Relations between evaporation coefficients and vegetation indices studied by model simulations. Remote Sensing of the Environment 50: 1-17.

Ellert, B.H.; Bettany, J.R. 1995. Calculation of organic matter stored in soils under contrasting management regimes. Canadian Journal of Soil Science 75: 529-538.

Empresa Brasileira de Pesquisa Agropecuária [Embrapa]. 2010. Climate database of Brazil. Available at: http://www.bdclima.cnpm. embrapa.br. [Accessed Aug. 02, 2010]. (in Portuguese).

Empresa Brasileira de Pesquisa Agropecuária. [Embrapa]. 1979. Manual for soil analysis methods. Rio de Janeiro: EmbrapaCNPS, Rio de Janeiro, RJ, Brazil. (in Portuguese).

Escola Superior De Agricultura "Luiz De Queiroz" [ESALQ/USP]. 2003. Database of automated meteorological station. Available at: http://ce.esalq.usp.br/dce/postoaut.htm. [Accessed Aug 28, 2003]. (in Portuguese).

Fagundes, J.L.; Da Silva, S.C.; Pedreira, C.G.; Sbrissia, A.F.; Carnevalli, R.A.; De Carvalho; C.A.; Pinto, L.F. 1999. Canopy characteristics and herbage accumulation of Cynodon spp submitted to different grazing intensities. Scientia Agricola 56: 1141-1149. (in Portuguese, with abstract in English).

Folegatti, M.V.; Camponez Do Brasil, R.P.; Blanco, F.F. 2001. Sampling equipment for soil bulk density determination tested in a kandiudalfic eutrudox and a typic hapludox. Scientia Agricola 58: $833-838$

Friedl, M.A. 1997. Examining the effects of sensor resolution and sub-pixel heterogeneity on spectral vegetation indices: Implications for biophysical modelling. p. 125-139. In Quattrochi, D.A.; Goodchild, M.F. Scale in remote sensing and GIS. Lewis, Boca Raton, FL, USA.

Gupta, R.K.; Prasad, T.S.; Vijayan, D. 2000. Relationship between LAI and NDVI for IRS LISS and Landsat TM bands. Advanced Space Research 26: 1047-1050. 
Henderson, T.L.; Szilagyi, A., Baumgardner; M.F., Chen, C.C.T. Landgrebe, D.A. 1989. Spectral band selection for classification of soil organic-matter content. Soil Science Society of America Journal 53: 1778-1784.

Henderson, T.L.; Baumgardner, M.F.; Franzmeier, D.P.; Stott, D.E.; Coster, D.C. 1992. High dimensional reflectance analysis of soil organic-matter. Soil Science Society of America Journal 865-872.

Hodgson, J.G. 1990. Grazing management: science into practice. Longman Scientific and Technical, Essex, UK.

Hummel, J.W.; Sudduth, K.A.; Hollinger, S.E. 2001 Soil moisture and organic matter prediction of surface and subsurface soils using an NIR soil sensor. Computers and Electronics in Agriculture 32: 149-165.

Ingram, J.S.I.; Fernandes, E.C.M. 2001. Managing carbon sequestration in soils: concepts and terminology. Agriculture Ecosystems Environment 87: 111-117.

Intergovernmental Panel on Climate Change [IPCC]. 2000. Land use, land-use change, and forestry special report. IPCC, Cambridge, UK.

Lal, R.; Cerri, C.C.; Bernoux, M.; Etchevers, J.; Cerri, C.E.P. 2006. Carbon Sequestration in Soils of Latin America. Food Products Press, Haworth Press, Binghamton, NY, USA. 554 p.

Levine, E.; Kimes, D.; Fifer, S.; Nelson, R. 2000. Evaluating tropical soil properties with pedon data, satellite imagery, and neural networks. p. 365-375. In Lal, R.; Kimble, J.M.; Stewart, B.A. (eds.), Global climate change and tropical ecosystems. CRC Press, Boca Raton, FL, USA.

Markham, B.L.; Barker, J.L. 1986. Landsat MSS and TM postcallibration on dynamic ranges of exoatmospheric reflectances and at satellite temperatures. Lanham, MD, USA. (Landsat Technical Notes).

Milne, E.; Al-Adamat, R.; Batjes, N.H.; Bernoux, M.; Bhattacharyya, T.; Cerri, C.C.; Cerri, C.E.P.; Coleman, K.; Easter, M.; Falloon, P.; Feller, C.; Gicheru, P.; Kamoni, P.; Killian, K.; Pal, D.K.; Paustian, K.; Powlson, D.; Rawajfih, Z.; Sessay, M.; Williams, S.; Wokabi, S. 2007. National and sub national assessments of soil organic carbon stocks and changes: the GEFSOC modelling system. Agriculture Ecosystems and Environment 122: 3-12.

Moraes, J.L.; Cerri, C.C.; Volkoff, B.; Bernoux, M. 1996. Soil properties under Amazon forest and changes due to pasture installation in Rondônia, Brazil. Geoderma 70: 63-81.
Moreira, M.A. 2001. Fundamentals and Applied Methods of Remote Sensing. INPE, São José dos Campos, SP, Brazil. (in Portuguese).

NASA. Landsat 7 science data users handbook 2009. Available at: http:/ /landsathandbook.gsfc.nasa.gov/handbook.html. [Accessed Feb. 10, 2010].

Oliveira, I.P.; Kluthcouski, J.; Yokoyama, L.P.; Dutra, L.G.; Portes, T.A.; Silva, A.E.; Pinheiro, B.S.; Ferreira, E.; Castro, E.M.; Guimarães, C.M.; Gomide, J.C.; Balbino, L.C. 1996. System Barreirão: Recovery of degraded pastures associated with annual cultures. EmbrapaCNPAF, Santo Antônio de Goiás, GO, Brazil. (in Portuguese).

Parton, W.J.; Schimel, D.S.; Cole, C.V.; Ojima, D.S. 1987. Analysis of factors controlling soil organic-matter levels in great-plains grasslands. Soil Science Society of America Journal 51: 11731179 .

Pino, F.A. 2009. Preliminary analysis of an agricultural census: Project Lupa in the state of São Paulo, Brazil. CATI, Campinas, SP, Brazil. 20 p. Available at: http://www.cati.sp.gov.br/ $\mathrm{p}$ r o j e t o l u p a / e s t u d o s - l u p a / Artigo_Lupa_Analise_Preliminar.pdf. [Accessed Nov. 14, 2010].(in Portuguese, with abstract in English).

Price, J.C.; Bausch, W.C. 1995. Leaf area index estimation from visible and near-infrared reflectance data. Remote Sensing of Environment 52: 55-65.

Reeves III, J.; McCarty, G.; Mimmo, T. 2003. The potential of diffuse reflectance spectroscopy for the determination of carbon inventories in soils. Environmental Pollution 116: 277-284.

Shonk, J.L.; Gaultney, L.D.; Schulze, D.G.; Vanscoyoc, G.E. 1991. Spectroscopic sensing of soil organic-matter content. Transactions of the ASAE 34: 1978-1984.

Trimble Navigation Limited. 1999. Characterizing accuracy of Trimble Pathfinder mapping receivers. Trimble Navigation Limited, Sunnyvale, CA, USA, 1999.

Turner, D.P.; Cohen, W.B.; Kennedy, R.E.; Fassnacht, K.S.; Briggs, J.M. 1999. Relationships between LAI and Landsat TM spectral vegetation indices across three temperate zone sites. Remote Sensing of Environment 70: 52-68.

US Geological Survey [USGS]. 2009. Landsat 7 Datasets Document. 2009. Available at: http://landsat.usgs.gov. [Accessed Feb. 10, 2010].

Received March 19, 2010

Accepted November 04, 2010 